\title{
HUBUNGAN PENGETAHUAN DAN SIKAP IBU DENGAN PERILAKU PEMBERIAN MAKANAN ANAK USIA 12-24 BULAN
}

\author{
Nuris Zuraida Rakhmawati, Binar Panunggal ${ }^{*}$ \\ Program Studi Ilmu Gizi Fakultas Kedokteran Universitas Diponegoro \\ Jl.Dr.Sutomo No.18, Semarang, Telp (024) 8453708, Email : gizifk@ undip.ac.id
}

\begin{abstract}
Background: Feeding for children will affected children nutritional status to make grow and develop normally. Lack of proper in giving food will make the children had poor nutrition. Mother's knowledge and attitude is needed to make a right choice about children's food. This study was aimed to analyze the correlation between knowledge and attitude with behavior pattern of giving food to children in the age 12-24 month.

Method: This was cross sectional study with 65 subjects at Puskesmas Pegandan. Mother's knowledge and attitude obtained by quesioner and behaviour pattern was obtained by interview and recall $5 \times 24$ hours. Indeep interview is needed to know mother's behaviour to feed the child. Bivariate analysis was conducted to know correlation between knowledge with the behaviour mother and correlation between attitude with the behaviour pattern.

Result: The result from this study are 86,15\% mother's has good knowledge, 76,92\% less in attitude and 73,95\% less in behaviour. Analyze data showed that there is a significant correlation between knowledge with the behaviour pattern $(p=0,003)$ and there is a significant correlation between attitude with the behaviour pattern $(p=0,04)$.

Consclusion: There was significant correlation between mother's knowledge and attitude with behavior pattern of giving food to children 12-24 month.
\end{abstract}

Key note: knowledge; attitude; behaviour; children

\begin{abstract}
ABSTRAK
Latar Belakang: Pemberian makanan pada anak dapat mempengaruhi status gizi sehingga pertumbuhan dan perkembangan anak normal. Kurangnya asupan makanan bergizi pada anak dapat membuat anak mengalami status gizi buruk. Pengetahuan dan sikap ibu diperlukan agar dapat memberikan makanan yang tepat untuk anak. Pada penelitian ini bertujuan untuk mengetahui hubungan pengetahuan dan sikap ibu terhadap perilaku pemberian makanan anak usia 12-24 bulan.

Metode: Desain penelitian cross sectional dengan jumlah subjek 65 ibu di wilayah Puskesmas Pegandan. Data yang diteliti meliputi pengetahuan dan sikap ibu dengan menggunakan kuesioner, serta perilaku yang diketahui dengan pengamatan, wawancara dan recall $5 \times 24$ jam. Wawancara mendalam dilakukan untuk mengetahui perilaku ibu dalam memberikan makan pada anak. Analisis bivariat dilakukan untuk mengetahui hubungan pengetahuan ibu dengan perilaku pemberian makan anak dan hubungan sikap ibu dengan perilaku pemberian makan anak.

Hasil: Hasil penelitian menunjukkan $86.15 \%$ ibu mempunyai pengetahuan baik, $76.92 \%$ ibu mempunyai sikap kurang dan $73.95 \%$ ibu mempunyai perilaku kurang. Analisis data menunjukkan adanya hubungan antara pengetahuan terhadap perilaku ibu dalam pemberian makanan untuk anak $(p=0,003)$ dan ada hubungan antara sikap dan perilaku ibu dalam pemberian makanan untuk anak $(p=0,04)$.
\end{abstract}

Simpulan: Terdapat hubungan pengetahuan dan sikap ibu terhadap perilaku pemberian makan anak usia 12-24 bulan.

Kata Kunci: pengetahuan; sikap; perilaku; anak

\section{PENDAHULUAN}

Masa pertumbuhan dan perkembangan paling pesat terjadi pada dua tahun awal kehidupan. Status gizi yang optimal pada baduta merupakan salah satu penentu kualitas sumber daya pada masyarakat sehingga penanganan tepat pada awal pertumbuhan akan mencegah gangguan gizi yang dapat muncul saat dewasa. ${ }^{1}$ Anak yang gizi baik juga harus mendapat perhatian gizi, hal ini di sebabkan pada usia ini anak rentan terkena gizi kurang sehingga bila tidak mendapat penanganan lebih lanjut dapat membuat anak mengalami penurunan status gizi buruk. ${ }^{2}$

Usia dua tahun pertumbuhan dan perkembangan anak membutuhkan gizi cukup yang dipengaruhi oleh faktor internal berupa genetik dan faktor eksternal berupa asupan makanan yang dikonsumsi setiap hari. ${ }^{3}$ Berdasarkan data WHO 2011, prevalensi anak gizi kurang di Indonesia mencapai $13 \%$ dan untuk angka kematian akibat gizi buruk mencapai $54 \% .{ }^{4}$ Menurut data Riskesdas tahun 2010, prevalensi kasus gizi kurang pada anak di propinsi Jawa

${ }^{*}$ Penulis Penanggungjawab 
Tengah sebesar $17,9 \%$ dan untuk gizi buruk mencapai angka 4,9\%. Salah satu penyebab gizi kurang pada anak adalah praktik pemberian makanan pada anak yang tidak tepat. ${ }^{5}$ Berdasarkan data WHO 2010, 1,5 juta anak meninggal karena pemberian makanan yang tidak tepat dan $90 \%$ diantaranya terjadi di negara berkembang. ${ }^{6}$

Pemberian makanan pada anak dapat dipengaruhi oleh pengetahuan dan sikap ibu serta adanya dukungan keluarga dan lingkungan. Pengetahuan dan sikap ibu akan mempengaruhi asupan makanan yang ada di dalam keluarga terutama anak. ${ }^{7,8}$ Penelitian yang dilakukan oleh Rinda menunjukkan hanya sekitar $62,5 \%$ ibu yang dapat mempraktikkan perilaku pemberian makan seimbang pada anak, $75 \%$ yang mempunyai sikap positif dalam pemberian makanan bergizi seimbang dan $54,2 \%$ ibu yang hanya mengerti pemberian makanan bergizi seimbang namun tidak dapat mempraktikkan dengan baik. ${ }^{9}$

Penelitian yang dilakukan oleh Evan menunjukkan pendidikan gizi pada orang tua atau keluarga yang mempunyai anak dapat merubah perilaku dari keluarga terutama dalam pemberian makan. ${ }^{10}$ Penelitian yang dilakukan oleh Ertem menunjukkan pemberian asupan makan yang tepat akan banyak dipengaruhi oleh keluarga sehingga dapat mempengaruhi asupan makan dan

status gizi anak. Pemberian makanan yang tepat meliputi pemberian makan utama dan camilan pada anak. ${ }^{11}$ Penelitian yang dilakukan oleh Askerning menunjukkan sikap ibu mengenai makanan pada anak akan mempengaruhi praktik ibu dalam pemberian makan anaknya. Sikap ibu dalam pemberian makan pada anak dapat mempunyai risiko 2,7 kali terhadap praktik ibu, dibandingkan dengan pengetahuan ibu yang tidak mempengaruhi perilaku. ${ }^{12}$ Berdasarkan gambaran di atas, peneliti tertarik untuk melakukan penelitian yang bertujuan mengetahui hubungan pengetahuan dan sikap terhadap perubahan perilaku ibu dengan pemberikan makan pada anak usia 12-24 bulan khususnya di Kota Semarang. Penelitian ini diharapkan dapat menambah pengetahuan mengenai pemberian makan anak yang tepat.

\section{METODE PENELITIAN}

Penelitian ini dilakukan pada 65 ibu yang mempunyai anak usia 12-24 bulan di wilayah kerja Puskesmas Pegandan karena pada wilayah kerja puskesmas terdapat 1132 anak dan 5 orang diantaranya mempunyai status gizi buruk. Waktu pelaksanaan penelitian ini selama 1,5 bulan, yaitu pada bulan Juli hingga awal September 2013. Penelitian ini menggunakan metode cross sectional. Kriteria inklusi dalam penelitian ini berupa ibu yang mempunyai anak usia 12-24 bulan yang sedang tidak dirawat di rumah sakit, anak tidak mengalami gangguan mental dan tidak memiliki kelainan bawaan serta ibu yang merawat anaknya tanpa bantuan pengasuh. Kriteria eksklusi dalam penelitian ini berupa ibu yang mengundurkan diri, ibu atau pun anak yang meninggal dunia dan pindah domisili.

Variabel bebas dalam penelitian ini berupa pengetahuan dan sikap ibu. Variabel terikat pada penelitian ini berupa perilaku ibu. Data yang dikumpulkan dalam penelitian ini berupa identitas, pengetahuan, sikap, dan perilaku sampel serta berat badan, tinggi badan, serta asupan anak. Pengetahuan merupakan hasil tahu seseorang dan dapat dilihat dari kemampuan untuk menjawab pertanyaan dengan benar yang diaktegorikan menjadi kurang dan baik dengan skala ordinal. Sikap merupakan pendapat dari tindakan ibu dalam penerapan teori yang mempunyai pilihan jawaban baik dan kurang dengan skala ordinal. Perilaku merupakan tindakan pemberian makanan pada anak yang diamati yang dapat dikategorikan dengan baik dan kurang dengan skala ordinal. Pengumpulan data pengetahuan dan sikap dapat diketahui dari kuesioner yang sebelumnya telah dilakukan validitas dan realibilitas sedangkan untuk perilaku ibu dalam pemberian makan anak dapat diketahui dengan pengamatan serta dilakukan juga wawancara secara mendalam. Pengumpulan data asupan makanan (energi, karbohidrat, lemak dan protein) dieproleh dengan wawancara menggunakan food recall $5 \times 24$ jam untuk mengetahui asupan makan anak. Instrumen pengambilan data terdiri atas 16 pertanyaan pengetahuan, 15 pertanyaan sikap dan 13 item perilaku yang diamati. Pemberian nilai pada pertanyaan pengetahuan dengan pemberian nilai 3 pada jawaban benar, 2 cukup benar dan 1 kurang benar. Ibu dikategorikan berpengetahuan baik apabila jawaban benar $\geq 80 \%$ dan kurang bila $<80 \% .{ }^{13}$ Pemberian nilai pada setiap jawaban sikap menggunakan skala likert berupa tidak setuju dan setuju. Ibu dikategorikan memiliki sikap baik apabila jawaban benar $\geq 80 \%$ dan kurang bila $<80 \% .{ }^{13}$ Pemberian nilai pada setiap perilaku ibu dengan nilai 1 apabila ibu sesuai dengan item yang diamati dan 0 bila tidak. Ibu dikategorikan memiliki perilaku baik apabila item perilaku ibu $\geq 80 \%$ dari seluruh item yang diamati dan memiliki perilaku kurang apabila item perilaku $<80 \%$ dari 
seluruh item yang diamati. ${ }^{13}$ Wawancara secara mendalam juga dilakukan untuk mengetahui lebih lanjut perilaku ibu dalam pemberian makan.

Tingkat pendidikan ibu dikelompokkan dalam tiga kategori yaitu ibu yang tidak lulus SD dan lulusan SD dikategorikan dalam kelompok berpendidikan rendah, lulusan SMP, SMK dan SMA dikategorikan berpendidikan sedang dan lulusan diploma dan sarjana dikategorikan kelompok yang mempunyai pendidikan tinggi. Status gizi pada anak usia 12-24 bulan dapat diketahui dari berat badan anak yang dibandingkan dengan usia anak. Status gizi anak dapat di dikelompokkan menjadi gizi kurang (-3 SD s/d -2 $\mathrm{SD})$, gizi baik (-2 SD s/d +2 SD) dan gizi lebih $(>+2 \mathrm{SD}) .{ }^{14}$ Data yang telah diperoleh dianalisis dengan menggunakan SPSS Analisis univariat dilakukan untuk mengidentifikasi data pengetahuan ibu,sikap ibu, pendidikan ibu, dan pendapatan keluarga, Analisis bivariat dilakukan dengan menggunakan uji Chi-Square untuk dapat melihat uji hubungan terhadap pengetahuan dengan perilaku dan sikap dengan perilaku.

\section{HASIL PENELITIAN \\ Karakteristik Anak}

Tabel 1. Gambaran Umur, Jenis Kelamin dan Status Gizi menurut BB/U

\begin{tabular}{lll}
\hline Variabel & n & \% \\
\hline Umur(bln) & & \\
$12-14$ & 14 & 21.5 \\
$15-17$ & 14 & 21.5 \\
$18-20$ & 22 & 33.8 \\
$21-24$ & 15 & 23.1 \\
\hline Total & 65 & 100 \\
\hline Jenis Kelamin & & \\
Laki-laki & 28 & 43.1 \\
Perempuan & 37 & 56.9 \\
\hline Total & 65 & 100 \\
\hline Status Gizi & & \\
Kurang & 12 & 18.5 \\
Baik & 53 & 81.5 \\
\hline Total & 65 & 100 \\
\hline
\end{tabular}

Tabel 2. Deskripsi Asupan Energi, Karbohidrat, Lemak dan Protein Anak

\begin{tabular}{llll} 
Variabel & Min & Max & Rerata \pm SD \\
\hline Asupan Energi(kkal) & 400.2 & 580 & $510.3 \pm 20.1$ \\
Asupan Karbohidrat(gr) & 60.3 & 82.3 & $79.9 \pm 13.2$ \\
Asupan Lemak(gr) & 32.5 & 54.4 & $45.1 \pm 20.1$ \\
Asupan Protein (gr) & 30.2 & 46.3 & $32.2 \pm 10.4$ \\
\hline
\end{tabular}

Berdasarkan tabel, rerata asupan energi karbohidrat 79,9 gram, lemak 45,1 gram dan anak usia 12-24 bulan sebesar 510,3 kkal, protein 32,2 gram.

\section{Karakteristik Ibu}

Tabel 3. Karakteristik ibu

\begin{tabular}{llc}
\hline Karakteristik ibu & n & \% \\
\hline Pendidikan & & \\
Tidak sekolah & 4 & 6.2 \\
SD & 7 & 10.8 \\
SLTP & 8 & 12.3 \\
SMA & 22 & 33.8 \\
SMK & 6 & 9.2 \\
\hline
\end{tabular}




\begin{tabular}{lll}
\hline D3 & 6 & 9.2 \\
S1 & 12 & 18.5 \\
\hline Total & 65 & 100 \\
\hline
\end{tabular}

Berdasarkan hasil penelitian, dapat diketahui sebagian besar ibu merupakan lulusan SMA $(33,8 \%)$.

Tabel 4. Skor pengetahuan, sikap dan perilaku ibu mengenai pemberian makan pada anak

\begin{tabular}{lll}
\hline Kategori & n & \% \\
\hline Pengetahuan & & \\
Baik & 56 & 86.1 \\
Kurang & 9 & 13.8 \\
\hline Total & 65 & 100 \\
\hline Sikap & & \\
Baik & 15 & 23.1 \\
Kurang & 50 & 76.9 \\
\hline Total & 65 & 100 \\
\hline Perilaku & & \\
Baik & 17 & 26.2 \\
Kurang & 48 & 73.8 \\
\hline Total & 65 & 100 \\
\hline
\end{tabular}

Berdasarkan hasil penelitian, diketahui banyak pada kategori kurang yaitu 50 ibu bahwa pengetahuan ibu mengenai makanan anak (76,9\%).Perilaku ibu mengenai makanan anak lebih banyak pada kategori baik yaitu sebanyak 56 lebih banyak pada kategori kurang yaitu sebanyak ibu $(86,1 \%)$. Sikap ibu mengenai makanan lebih 48 ibu $(73,8 \%)$.

Tabel 5. Rerata pengetahuan, sikap dan perilaku mengenai pemberian makan pada anak

\begin{tabular}{llll} 
Kategori & Min & Max & Rerata \pm SD \\
\hline Pengetahuan Ibu & 43.7 & 100 & $87.3 \pm 12.6$ \\
Sikap Ibu & 40 & 100 & $77.7 \pm 11.9$ \\
Perilaku & 53.8 & 100 & $74.9 \pm 10.6$ \\
\hline
\end{tabular}

Berdasarkan hasil penelitian rerata Hubungan Pengetahuan dan Sikap dengan pengetahuan ibu adalah 87,3 ; sikap ibu memiliki Perilaku Ibu rerata 77,7 dan perilaku ibu memiliki rerata 74,9.

Tabel 6. Pengetahuan, dan Sikap dengan Perilaku Ibu

\begin{tabular}{|c|c|c|c|c|}
\hline \multirow[t]{2}{*}{ Variabel } & \multicolumn{2}{|c|}{ Perilaku } & \multirow[t]{2}{*}{$p$ value } & \multirow[t]{2}{*}{$\mathbf{R P}$} \\
\hline & $\begin{array}{r}\text { Kurang } \\
\mathbf{n}(\%)\end{array}$ & $\begin{array}{l}\text { Baik } \\
\text { n(\%) }\end{array}$ & & \\
\hline \multicolumn{5}{|l|}{ Pengetahuan } \\
\hline Kurang & $7(31.8 \%)$ & $2(4.7 \%)$ & 0.003 & 1.33 \\
\hline Baik & $15(68.2 \%)$ & $41(95.3 \%)$ & & \\
\hline Total & $22(100 \%)$ & $43(100 \%)$ & & \\
\hline \multicolumn{5}{|l|}{ Sikap } \\
\hline Kurang & $14(77.7 \%)$ & $28(76.9 \%)$ & 0.04 & 1.19 \\
\hline Baik & $8(22.3 \%)$ & $15(23.1 \%)$ & & \\
\hline Total & $22(100 \%)$ & $43(100 \%)$ & & \\
\hline
\end{tabular}


Berdasarkan hasil penelitian diketahui ada hubungan pengetahuan dengan perilaku ibu $(\mathrm{p}<0,05)$ dan terdapat hubungan sikap dengan perilaku ibu(p<0,05).

\section{Analisis Kualitatif}

Analisis data kualitatif dilakukan untuk mendeskripsikan perilaku ibu dalam memberikan makan pada anak usia 12-24 bulan. Wawancara mendalam dilakukan pada 12 ibu yang mempunyai anak dengan status gizi kurang dan gizi baik. Hal ini dilakukan untuk dapat menggali perilaku ibu dalam memberikan makan pada anak.

Tabel 7. Gambaran Perilaku ibu dalam Pemberian Makan Anak

\begin{tabular}{|c|c|c|}
\hline NO & $\begin{array}{c}\text { Umur } \\
\text { Subyek } \\
\text { (bulan) }\end{array}$ & Perilaku Ibu \\
\hline 1 & 20 & $\begin{array}{l}\text { Anak tidak suka mengkonsumsi sayur sehingga ibu akan menyuapi anak } \\
\text { dengan tambahan lauk dan kuah sayur. Ibu tidak mau mencoba menyuapi } \\
\text { anak dengan sayur, dengan alasan anak anak tidak suka. Ibu tidak mencoba } \\
\text { memperkenalkan sayur pada anak, dengan anggapan anak akan suka sayur } \\
\text { bila sudah besar. }\end{array}$ \\
\hline 2 & 12 & $\begin{array}{l}\text { Anak terbiasa diberikan makanan camilan sebelum mengonsumsi makanan } \\
\text { utama, sehingga anak tidak terlalu banyak menghabiskan makanan } \\
\text { utamanya. Hal ini dilakukan agar anak terpancing mengonsumsi makanan } \\
\text { utama, walau terkadang makanan utama sering tidak habis dikarenakan anak } \\
\text { sudah kenyang karena telah mengonsumsi makanan jajajanan. }\end{array}$ \\
\hline 3 & 12 & $\begin{array}{l}\text { Anak terbiasa mengonsumsi bakwan setiap harinya. Hal ini dikarenakan } \\
\text { anak hanya mau mengonsumsi sayur dalam bentuk bakwan. Namun sayur } \\
\text { yang digunakan di dalam bakwan hanya berupa kubis dan wortel. Ibu tidak } \\
\text { mencoba modifikasi makanan lain dikarenakan ibu beranggapan ribet bila } \\
\text { hanya mempersiapkan makanan untuk anak saja sedangkan tugas rumah } \\
\text { yang harus ibu lakukan cukup banyakk. Sehingga menurut ibu, bakwan } \\
\text { merupakan pemilihan yang praktis. }\end{array}$ \\
\hline 4 & 16 & $\begin{array}{l}\text { Anak lebih suka mengonsumsi makanan camilan sehingga anak susah untuk } \\
\text { makan utama. Ibu hanya menyuapi anak tidak lebih dari } 3-4 \text { sendok. } \\
\text { Selebihnya anak diberikan makan krupuk, biskuit, roti yang biasa di jual di } \\
\text { warung, Ibu tidak pernah memaksa anak untuk makan dikarenakan anak } \\
\text { suka untuk memberontak sehingga ibu akan menunggu anak untuk minta } \\
\text { makan. }\end{array}$ \\
\hline 5 & 15 & $\begin{array}{l}\text { Ibu hanya memberikan makan bila anak meminta, hal ini dikarenakan ibu } \\
\text { menganggap bila anak tidak meminta makan berarti anak tidak lapar. Selain } \\
\text { itu ibu hanya masak di pagi hari saja namun untuk dimakan dari pagi hingga } \\
\text { malam. Ibu memberikan makan anak sesuai dengan saran dari tetangga } \\
\text { dikarenakan disekitar rumah mengatakan bahwa anak balita lebih suka } \\
\text { mengonsumsi camilan dibandingkan mengonsumsi makanan utama. } \\
\text { Sehingga ibu tidak melarang anak dalam memilih makanan yang diinginkan. } \\
\text { Pemilihan makanan jajanan anak biasanya dilakukan sesuai dengan } \\
\text { keinginan anak seperti coklat dan biskuit yang biasa di jual di warung. }\end{array}$ \\
\hline 6 & 19 & $\begin{array}{l}\text { Anak susah untuk makan meskipun ibu sudah berusaha membujuk anak } \\
\text { untuk makan. Ibu sudah berusaha menyuapi anak agar anak dapat } \\
\text { menghabiskan makanannya. Anak cenderung suka membeli camilan di } \\
\text { warung dikarenakan tetangga rumah yang juga mempunyai anak seumuran } \\
\text { suka mengajaknya untuk membeli jajanan di warung. }\end{array}$ \\
\hline 7 & 15 & $\begin{array}{l}\text { Ibu hanya memberikan lauk ayam goreng pada anak, karena anak hanya mau } \\
\text { makan bila ada lauk ayam. Ibu pernah mencoba memperkenalkan anak } \\
\text { dengan lauk lain, tapi anak susah untuk menerimanya. Sehingga ibu lebih } \\
\text { suka memberikan anak makanan dengan lauk ayam dikarenakan ibu }\end{array}$ \\
\hline
\end{tabular}




\begin{tabular}{|c|c|l|}
\hline & & menganggap anak dapat makan dengan lahap. \\
\hline 8 & 14 & $\begin{array}{l}\text { Ibu terbiasa membeli makan di warung untuk lauk, hal ini dikarenakan } \\
\text { jumlah anak yang banyak di rumah sehingga ibu malas untuk masak dalam } \\
\text { jumlah banyak. Anak susah makan, hanya mau makan 5-6 sendok makan } \\
\text { saja.Sehingga ibu akan membujuk anak agar dapat makan dengan jajanan } \\
\text { yang ada di warung seperti coklat atau kue. Bila anak sudah kenyang dengan } \\
\text { jajanan, anak biasa tidak makan siang dan ibu tidak mempermasalahkannya } \\
\text { dikarenakan ibu menganggap anak sudah kenyang. }\end{array}$ \\
\hline 9 & 15 & $\begin{array}{l}\text { Ibu membiasakan anak untuk makan dengan lauk yang seadanya seperti tahu } \\
\text { atau tempe goreng, selain itu ibu menambahkan sayur bayam walau anak } \\
\text { hanya mau makan 2 suap saja. Anak susah makan sayur selain sayur bayam. }\end{array}$ \\
\hline 10 & 16 & $\begin{array}{l}\text { Anak lebih suka mengkonsumsi mie goreng dengan telur goreng. Anak tidak } \\
\text { suka mengkonsumsi makan sayur. Anak mau makan nasi namun hanya habis } \\
\text { 5-6 sendok saja. Ibu mengikuti keinginan anak untuk makan mie goreng } \\
\text { dikarenakan anak dapat menghabiskan makanannya. }\end{array}$ \\
\hline 11 & 20 & $\begin{array}{l}\text { Ibu suka membujuk anak untuk makan dengan membelikannya camilan di } \\
\text { warung seperti coklat atau makanan ringan. Apabila anak sudah } \\
\text { mengkonsumsi camilan, anak tidak menghabiskan makanan utamanya. } \\
\text { Namun bila ibu tidak membelikan camilan, anak tidak mau makan. }\end{array}$ \\
\hline 12 & 18 & $\begin{array}{l}\text { Ibu tidak dapat membeli lauk yang cukup dalam keluarga sehingga tidak ada } \\
\text { lauk yang khusus untuk anak. Ibu akan menyuapi anak dengan krupuk, } \\
\text { bakwan atau kue yang ada di warung bila anak masih lapar. }\end{array}$ \\
\hline
\end{tabular}

Hasil wawancara dan pengamatan langsung menunjukkan 12 ibu masih berperilaku kurang dalam memberikan makan pada anak mereka.

\section{PEMBAHASAN}

Dari hasil penelitian, tingkat pendidikan ibu yang paling banyak ditemukan merupakan lulusan SMA (33,8\%). Pendidikan dapat mempengaruhi proses belajar seseorang, semakin tinggi pendidikan seseorang akan mudah dalam menerima informasi yang ada. Semakin banyak informasi yang masuk maka semakin banyak pengetahuan yang didapat termasuk informasi mengenai kesehatan. Semakin tinggi pendidikan seseorang maka pengetahuan seseorang tersebut akan semakin tinggi. Namun seseorang yang berpendidikan rendah belum tentu berpengetahuan rendah juga. ${ }^{15}$

Pada penelitian ini menunjukkan adanya hubungan antara pengetahuan dengan perilaku ibu. Hasil penelitian ini didukung dengan penelitian yang dilakukan oleh Ikhwansyah, dimana pendidikan dan pengetahuan akan berhubungan secara bermakna dengan perilaku ibu dalam memberikan makan. ${ }^{16}$ Hubungan pengetahuan dengan perilaku ibu dalam memberikan makan pada anak didapatkan nilai rasio prevalensi (RP) sebesar 1,33. RP > 1 dapat disimpulkan bahwa pengetahuan mempunyai hubungan yang positif dengan perilaku dimana ibu yang mempunyai pengetahuan kurang dapat berpeluang untuk berperilaku kurang.

Pendidikan yang tinggi dapat mempengaruhi perilaku ibu dalam pemberian makan pada anak. Ibu yang mempunyai pendidikan tinggi, diharapkan mempunyai daya terima yang lebih baik terhadap ilmu yang diterima sehingga diharapkan dapat dipraktikkan pada keluarga. Namun pendidikan yang rendah, tidak menjamin seorang ibu tidak mempunyai cukup pengetahuan mengenai makanan pada keluarga. Adanya rasa ingin tahu yang tinggi dapat mempengaruhi ibu dalam mendapatkan informasi mengenai makanan yang tepat untuk anak. ${ }^{16}$ Sementara penelitian yang dilakukan oleh Henny menunjukkan adanya hubungan yang signifikan antara pengetahuan ibu dengan pemberian makanan pada balita. ${ }^{9}$ Penelitian lain yang dilakukan oleh Kodyat menunjukkan semakin tingggi pendidikan dapat mempermudah dalam mencerna informasi baru sehinga mempengaruhi pengetahuan. ${ }^{17}$

Pada 65 ibu yang menjadi sampel penelitian, ibu yang memiliki pengetahuan baik dengan perilaku kurang yaitu sebesar $68,2 \%$ sehingga dapat diketahui bahwa pengetahuan yang baik akan mempengaruhi perilaku ibu. Hasil 
penelitian ini didukung dengan penelitian Cahyo dimana pengetahuan mempunyai hubungan dengan perilaku seseorang dalam memutuskan makanan yang dikonsumsinya. ${ }^{18}$ Menurut penelitian yang dilakukan Agriati pengetahuan ibu mengenai makanan pada anak di desa Mangon termasuk kategori baik yanitu sebanyak $82,4 \%$ dan sikap ibu mengenai pemberian makan pada anak sebesar $52,7 \%$ sehingga mempengaruhi praktik ibu sebesar $69,2 \%{ }^{19}$ Dari hasil wawancara mendalam, diketahui bahwa banyak ibu balita yang sudah memiliki pengetahuan yang bagus mengenai makan anak namun masih belum dapat berperilaku secara tepat seperti adanya variasi makanan pada anak untuk pengenalan makan pads anak sejak dini. Faktor malas dan status ekonomi pada keluarga kemungkinan merupakan alasan utama ibu dalam menghidangkan makanan di keluarga sehingga anak akan mendapatkan makanan yang sama atau mendapatkan dalam porsi kecil.

Pada hasil penelitian antara sikap dengan perilaku ibu menunjukkan adanya hubungan yang positif. Hal ini dapat diketahui dengan adanya RP $>1$ sehingga dapat disimpulkan bahwa sikap kurang dapat berpeluang untuk berperilaku kurang. Hasil penelitian ini didukung dengan penelitian Askerning dimana ibu yang mempunyai sikap baik mengenai pemberian makanan yang tepat pada anak akan berbanding lurus dengan perilakunya. ${ }^{12}$ Untuk dapat mempengaruhi perilaku, sikap mempunyai tiga komponen yang dapat membentuk perilaku dan dipengaruhi dengan pengetahuan, pikiran, keyakinan serta emosi. Namun sikap belum tentu langsung dapat terwujud dalam suatu tindakan, diperlukan faktor pendukung seperti keluarga sehingga dapat mewujudkan suatu tindakan. $^{20}$

Sikap ibu mengenai pemberian makanan pada anak merupakan faktor yang menentukan seseorang untuk berperilaku memberikan makanan yang tepat untuk anak. Makanan yang tepat buat anak diberikan agar anak dapat memenuhi kebutuhan gizinya. Sikap ibu yang yang di dapat dari interaksi sosial seperti lingkungan, dapat dengan mudah mempengaruhi perilaku ibu dalam memberikan makanan di rumah. Menurut penelitian yang dilakukan oleh Hafrida, kebiasaan makan yang diajarkan ibu kepada anak akan mempengaruhi pola makan anak sehingga anak dapat memutuskan makanan yang dikonsumsinya. ${ }^{21}$ Data di Indonesia menunjukkan $13 \%$ baduta mengalami keterlambatan perkembangan dikarenakan pendapatan yang kurang membuat keluarga tidak dapat membeli makanan yang dapat dimakan seluruh anggota keluarga. $^{22}$ Namun pada peneltian Liu et all menunjukkan status ekonomi pada keluarga kurang berpengaruh terhadap perkembangan anak (31,5\%). Status ekonomi pada keluarga akan berpengaruh terhadap sikap ibu dalam pemberian makanan yang tepat pada keluarga khususnya anak. $^{23}$

Pada wawancara mendalam yang dilakukan, sikap ibu dalam memberikan makanan masih banyak dipengaruhi oleh keinginan anak mereka. Jika balita tidak mau makan makanan keluarga dan lebih memilih makanan camilan, maka ibu menganggap hal tersebut merupakan hal biasa. Hal ini juga di dukung dengan sikap ibu dalam memilih makanan camilan buat anak, pembelian camilan seperti makanan ringan, coklat atau krupuk dianggap dapat menggantikan posisi makanan utama karena anak akan merasa kenyang. Hal ini didukung dengan penelitian Cholic bahwa sikap ibu dalam memilih makanan anak banyak dipengaruhi oleh anaknya. Sehingga sikap ibu berhubungan dengan perilaku yang salah dalam pemberian makan pada anaknya. ${ }^{24}$

\section{SIMPULAN}

Terdapat hubungan pengetahuan ibu dengan perilaku pemberian makanan anak usia $12-24$ bulan $(\mathrm{p}<0,05)$ dan terdapat hubungan sikap ibu dengan perilaku pemberian makanan anak usia $12-24$ bulan $(\mathrm{p}<0,05)$

\section{SARAN}

Perlu adanya pemberian informasi praktis mengenai modifikasi makanan yang disenangi oleh anak.

\section{DAFTAR PUSTAKA}

1. Merryana, Bambang. Peranan Gizi dalam Siklus Kehidupan. Jakarta: Kencana Prenada Media Group. 2012.

2. UNICEF. Tracking Progress on child and maternal nutrition- A Survival and Development Priority. 2009.

3. Ministry of Health. Food and Nutrition Guidelines for Healthy Infants andd Toddlers(aged 0-2): A background paper $\left(4^{\text {th }}\right.$ Ed). New Zealand : Ministry of Health. 2008.

4. World Health Organization. World Health Statistics. 2011.

5. Departemen Kesehatan Republik Indonesia. Riset Kesehatan Dasar 2010. Jakarta: Badan Penelitian dan Pengembangan Kesehatan Kementerian Kesehatan RI. 2010. 
6. World Health Organization. World Health Statistics. 2010.

7. Puslitbang Gizi dan Makanan. Departemen Kesehatan RI. Keluarga Sadar Gizi (KADARZI) dalam Menuju Gizi Baik Untuk Semua. 2005.

8. Sulistyowati, Henny. Hubungan antara Pengetahuan Ibu dan Pola Pemberian Makanan Pendamping ASI dengan Status Gizi Balita usia 424 bulan di Desa Sendangharjo Kecamatan Blora Kabupaten Blora (skripsi). Semarang : Universitas Negeri Semarang. 2004.

9. Intansari, Rinda. Pengetahuan, Sikap dan Praktik Pemberi Makanan Bergizi Seimbang di Cikarang Barat Bekasi. 2009.

10. Evan,Alexandria, Rafroin et al.Nutrition Knowledge, Attitudes, and Practices among Nutrition Educators in the South American Journal of Helath. 2005

11. Ertem, Atay, Dogan, et al. Mother Knowledge of Young Child Development in a Developing Country. Journal Compilation. 2007.

12. Askerning. Sikap dan Perilaku Keluarga dalam Pengasuhan Anak. Jakarta : Rineka Cipta; 2007.

13. Ali Khomsan. Teknik pengukuran pengetahuan gizi. Bogor: Institut Pertanian Bogor. 2000.

14. Kementrian Kesehatan. Riset Kesehatan Dasar (Riskesdas). Kemenkes RI; Jakarta.2011.

15. Widayatun. Ilmu Perilaku. Jakarta : Rineka Cipta; 2004.

16. Ikhwansyah. Hubungan Pengetahuan Ibu dengan Status Gizi Anak. 2007.

17. Kodyat. Pokok-Pokok Kegiatan Program Perbaikan Gizi pada PJP II untuk Menanggulangi Masalah Gizi Salah.1994.

18. Cahyo. Gambaran Pengetahuan dan Sikap Ibu dalam Pemberian Makan Anak pada Balita di Desa Hagarmanah Jatinagor(skripsi). Bandung : Universitas Padjajaran. 2003.

19. Agriati. Hubungan Pengetahuan, Sikap da Perilaku Ibu dalam pemberian MP-ASI.(skripsi). Jakarta : UIN Syarif Hidayatullah.2011.

20. Soekidjo. Pendidikan Kesehatan dan Perilaku Kesehatan.Edisi 2. Jakarta: Rineka Cipta; 2003.

21. Hafrida. Studi Positive Deviance pada Keluarga Miskin yang Mempunyai Anak Usia 12-24 bulan di Kelurahan Belawan Bahari Kecamatan Medan. (skripsi). Medan : Universitas Sumatra Utara.2004.

22. Departemen Kesehatan Republik Indonesia. Tim Peneliti Direktorat Bina Kesehatan Keluarga dan Dirktorat Kesehatan Jiwa. Laporan Akhir Penelitian Pengembangan Perkembangan Anak. 1990.

23. Liu, Raine, Venables et al. Malnutrition at age 3 years and lower cognitive ability at age under 2 years. Journal Compilation. 2010.

24. Cholic.Gambaran Pengetahuan Sikap Ibu dalam Pemberian Makanan Keluarga.(skripsi). Bandung : Universitas Padjajaran. 2009. 